Original Research Article

\title{
Drug utilization study of antihypertensive drugs in a tertiary care hospital
}

\author{
A. R. Radhika*
}

Department of Pharmacology, Government Medical College, Mahabubnagar, Telangana, India

Received: 10 October 2018

Revised: 20 October 2018

Accepted: 24 October 2018

*Correspondence to:

Dr. A. R. Radhika,

Email: drradhikarayan@ gmail.com

Copyright: () the author(s), publisher and licensee Medip Academy. This is an openaccess article distributed under the terms of the Creative Commons Attribution NonCommercial License, which permits unrestricted noncommercial use, distribution, and reproduction in any medium, provided the original work is properly cited.

\begin{abstract}
Background: Hypertension is a major common disease and effects a million of people worldwide. And is risk factor for other diseases like cardiovascular diseases, stroke etc. The aim of our study was undertaken to study the utilization pattern of anti hypertensive drugs at a tertiary care hospital. The guidelines for the treatment of hypertension are put forward by the Joint National Committee (JNC) on detection, evaluation and treatment of blood pressure. The Indian guidelines endorsed by the cardiology society of India, the hypertension society of India, and Indian college of physicians closely follow the JNC guidelines.

Methods: A prospective cross-sectional observational study was conducted on 100 patients in outpatient Department of General medicine of Government General Hospital, Mahabubnagar district, Telangana. The data collected was analysed from the prescription pattern of anti hypertensive drugs. The data collected were statistically analysed and presented as counts and percentages.

Results: Out of 100 study subjects, males were $55 \%$ and females were $45 \%$ and maximum number of patients in age group are (51 to 60 years.). Among antihypertensive drugs commonly used in present study are Losartan (ARB's)$64 \%$ and for two drug therapy are enalapril and amlodipine $22 \%$ and for three drug therapy are enalapril +atenolol+furosemide-14\%. Average number of drugs prescribed is $6.15 \%$ per prescription. Percentages of medicines prescribed by generic drugs are $85 \%$ and from the essential drug list are $95 \%$.

Conclusions: In this study usage of anti hypertensive drugs were prescribed rationally in tertiary care hospital. The study emphasizes that need for effective continuing medical education and also preventive measures in hypertensive individuals.
\end{abstract}

Keywords: Anti hypertensives, Angiotensin receptor blockers, Drug utilization study, Hypertension

\section{INTRODUCTION}

Hypertension represents an enormous global public health case challenge. The world health organization (WHO) has projected that 1.5 billion people globally are likely to suffer from hypertension by 2025 . Hypertension is the leading risk to morbidity and mortality. The overall prevalence for hypertension in India was estimated to be $29.8 \%$ according to a study by Anclala $\mathrm{R}$ et al. $^{1}$ Hypertension is associated with stroke deaths (57\%) and $24 \%$ of all coronary deaths. ${ }^{2}$ Appropriate management of
Hypertension can lower the incidence of all associated diseases. With increased use of anti hypertensive drugs, improves quality of life, reduces the risk mortality and morbidity. The guidelines for the treatment of hypertension are put forward by the Joint National Committee (JNC) on detection, evaluation and treatment of blood pressure.

Drug utilization and prescribing pattern studies are an important research tool by which the impact that such guide lines have on the selection of therapeutic agents can be assessed and analysed. 
The WHO defines drug utilization studies as the marketing, distribution, prescription and the use of drugs in society with special emphasis on the resulting medical social and economic consequences. ${ }^{3,4}$

Drug utilization studies is one of the important measuring tools for measuring prescribing practices in health facility, distinguishing areas for betterment and developing drug prescribing practices, promote rational prescribing practices, reduce morbidity and mortality and decrease the economic burden in their cost of illness. Drug utilization data is required for analysing annual drug acquisition cost, drug supply to the subjects drugs over or under utilization, drug pricing cost, cost consumption analysis and use.

The anatomical therapeutic chemical (ATC) and defined daily dose (DDD) methodologies are most important tool for measuring drug use. The anatomical, therapeutic, chemical classification systems serve as an international standard for classifying drugs.

Defined daily dose (DDD) is an important unit of measurement in drug utilization studies. The main purpose of using ATC and DDD systems is to compare data between countries.

Present study aim is to evaluate the prescription of antihypertensive drugs in Government General Hospital, Mahabubnagar District, Telangana a tertiary care hospital.

\section{METHODS}

A prospective, cross-sectional observational study was conducted in 100 subjects in outpatient of Department of General medicine, Government Medical College, Mahabubnagar, Telangana, from duration of 3 months (July-2018 to September 2018). Before initiation of study, the approval of institutional Ethics Committee was obtained.

\section{Inclusion criteria}

- Subjects who are newly diagnosed and established history of hypertension

- $\quad$ Subjects who are $\geq 20$ years and above as well as both the genders

- Hypertensive patient's systolic blood pressure as $\geq 140 \mathrm{~mm} \mathrm{Hg}$ and diastolic blood pressure $\geq 90 \mathrm{~mm} \mathrm{Hg}$ at the time of diagnosis were included in the study.

\section{Exclusion criteria}

- Subjects with significant hepatic and real diseases

- Pregnant women

- Chronically ill patients and psychiatric illness.

\section{Data collection and analysis}

Data was collected over a period of three months from July 2018 to September 2018. A predesigned pretested schedule was employed to collect the data. The schedule contained information was pertaining to basic demographic variable like age, sex, medical historycomorbid condition, and a format to assess the antihypertensive drugs prescribed.

Prescribed anti hypertensive's were classified into angiotensin receptor blockers (ATC code -C09), angiotensin converting enzyme inhibitors (ATC code C09), calcium channel blockers (ATC code C-08), betablockers (ATC code C-07), loop diuretic (ACT codeC03). The data was collected, and WHO core drug prescribing indicators was analysed.

\section{RESULTS}

A total of 100 patients are included in this study and the prescription was analysed. Among them males were 55\% and females were $45 \%$ and maximum no. of patients in age group are 51 to 60 years.

Majority of study subjects were observed to be in the age group of 51-60 years (42\%) followed by 61 to 70 years $(24 \%)$ and 41 to 50 years $(22 \%)$, and in the age group 31 40 years (6\%), 71 to 80 years $(4 \%)$, and 20 to 30 years $2 \%$. Majority of study subjects were previously diagnosed $92 \%$ (old cases), and $8 \%$ were new cases.

Among the patients receiving prescribed antihypertensives, the most commonly used drug as monotherapy was losartan (64\%) which is an angiotensin receptor blocker. As a two-drug therapy, enalapril (angiotensin converting enzyme inhibitor), and amlodipine (calcium channel blockers) was prescribed in $22 \%$ of patients. $14 \%$ of the patients received three drug therapy which was enalapril+ atenolol (betablockers) + furosemide (loop diuretic). This is depicted in Table 1 which shows prescribing pattern of different antihypertensives and their frequency.

Table 1: Prescribing pattern of antihypertensives in study subjects.

\begin{tabular}{|lllc|}
\hline & $\begin{array}{l}\text { No. of } \\
\text { patients }\end{array}$ & $\begin{array}{l}\text { Most commonly } \\
\text { used drugs }\end{array}$ & $\%$ \\
\hline Monotherapy & 64 & Losartan & 64 \\
\hline $\begin{array}{l}\text { Two drug } \\
\text { therapy }\end{array}$ & 22 & $\begin{array}{l}\text { Enalapril+ } \\
\text { Amlodipine }\end{array}$ & 22 \\
\hline $\begin{array}{l}\text { Three drug } \\
\text { therapy }\end{array}$ & 14 & $\begin{array}{l}\text { Enalapril+ Atenolol+ } \\
\text { Furosemide }\end{array}$ & 14 \\
\hline
\end{tabular}

The antihypertensive prescribing pattern were analysed according to the study protocol by obtaining defined daily dose (DDD) and compared with WHO-DDD.

DDD was obtained as follows

Drug usage DDD=

No. of items used*amount of drug per item (mg) WHO recommended DDD of a drug 


\section{*DDD=Defined Daily Dose}

As represented in Table 2, the comparison obtained in our study shows no much difference in the WHO-DDD and obtained DDD in ACE inhibitors (enalapril and ramipril), whereas telmisartan (ARBs) and atenolol (beta blocker) shows very less obtained DDD when compared to WHODDD.

Table 2: Comparison of DDD obtained from present study with the WHO-DDD.

\begin{tabular}{|c|c|c|c|}
\hline $\begin{array}{l}\text { Name of the } \\
\text { drug }\end{array}$ & ATC code & $\begin{array}{l}\text { WHO- } \\
\text { DDD } \\
\text { (mg) }\end{array}$ & $\begin{array}{l}\text { Obtained } \\
\text { DDD } \\
(\mathrm{mg})\end{array}$ \\
\hline \multicolumn{4}{|c|}{ ACE inhibitors } \\
\hline Enalapril & CO9AA02 & 10 & 15 \\
\hline Ramipril & C09AAO5 & 2.5 & 2.6 \\
\hline \multicolumn{4}{|c|}{ ARB's (Angiotensin receptor blockers) } \\
\hline Losartan & C09CA01 & 50 & 40 \\
\hline Telmisartan & C09CA07 & 40 & 2.6 \\
\hline \multicolumn{4}{|l|}{ Loop diuretic } \\
\hline Furosemide & C03CA01 & 40 & 55 \\
\hline \multicolumn{4}{|l|}{ Betablockers } \\
\hline Atenolol & C07AB03 & 75 & 26 \\
\hline \multicolumn{4}{|c|}{ Calcium channel blockers } \\
\hline Amlodipine & C08CA01 & 5 & 14 \\
\hline
\end{tabular}

In present study, on accessing the prescribing indicators, the average drugs prescribed per prescription were $6.15 \%$ and generic drugs prescribed were $85 \%$. The drugs prescribed from essential drug list were 95\%. Other drugs prescribed, commonly along with antihypertensives were metformin, aspirin, antimicrobials, antiulcer agents, and also injections like insulin. These indicators are shown in Table 3 .

Table 3: Prescribing indicators.

\begin{tabular}{|ll|}
\hline Prescribing indicators & $\begin{array}{l}\text { Data } \\
\text { (Percentage) }\end{array}$ \\
\hline Average drugs prescribed/prescription & 6.15 \\
\hline Generic drugs & 85 \\
\hline Antihypertensives & 100 \\
\hline Metformin & 26 \\
\hline Aspirin & 20 \\
\hline Antimicrobials & 15 \\
\hline Antiulcer & 35 \\
\hline Injections & 8 \\
\hline On essentials drug therapy & 95 \\
\hline
\end{tabular}

Present study also analysed the prescribing pattern of antihypertensives in diabetic patients (that is a subject suffering from both hypertension and diabetes) which is represented in Table 4.

Most commonly prescribed antihypertensives in diabetic patients was enalapril as monotherapy, losartan and amlodipine as two drug therapy and enalapril, amlodipine and atenolol as three drug therapy.

\section{Table 4: Prescription pattern of antihypertensive drugs in diabetic patients.}

\begin{tabular}{|l|l|}
\hline Most commonly used & $\begin{array}{l}\text { Montihypertensive drugs in } \\
\text { antherapy }\end{array}$ \\
\hline diabetic patients \\
\hline Enalapril \\
\hline Three drug therapy & Losartan+ Amlodipine \\
\hline
\end{tabular}

\section{DISCUSSION}

A total of 100 subjects were included in the study and their prescriptions were analysed. Among them males were 55\% and females were $45 \%$. In present study distribution of males and females Patients. Males are more when compare to females. These reflects the overall higher prevalence of the disease process in the male gender and associated with other factors such as cigarette smoking, alcohol consumption, strenuous lifestyle etc. ${ }^{5}$ A relative male preponderance also observed in other studies like Xavier D et al, pattern of drug use in hypertension in tertiary care hospital. ${ }^{6}$ Age group of 51 to 60 years (42\%), and 61-60 years $(24 \%)$. These show that the disease process is linked to late middle age and the elderly age group. Many studies have been quoted that various factors are responsible to the development of hypertension and diabetes mellitus in the susceptible age group. ${ }^{7,8}$ Out of 100 patients $92 \%$ are old cases and $8 \%$ are newly diagnosed. These show that better awareness and better tool are available to physicians even in relatively remote areas. Early detection appropriate treatment of hypertension and diabetes can vastly reduce the morbidity and mortality.

The main purpose of DDD system was to provide a tool for presenting drug utilization studies, which would allow the measurement of drug consumption across the therapeutic group. Coming to the prescribing pattern of different antihypertensive drugs. The most commonly used drug is losartan which is an angiotensin receptor blocker. In present study losartan is commonly use antihypertensive frequently. A similar study is also observed in some other study like Beg MA, et al. A study on drug prescribing pattern in hypertensive patients in tertiary care teaching hospital at Dehradun, Uttarkand. ${ }^{9}$

Other drugs commonly used are enalapril (ACE inhibitor) and amlodipine (CCB) atenolol (Beta-Blocker). Next is furosemide (loop diuretic). In a study Mohd $\mathrm{AH}$ et al, the most commonly prescribed antihypertensive drugs among elderly was amlodipine. ${ }^{8}$

Similarly, in study by Kaur $\mathrm{S}$ et al, the angiotensin converting enzyme inhibitors and calcium channel blockers were the most commonly prescribed antihypertensive drugs followed by beta-blockers and loop 
diuretic. ${ }^{10}$ This pattern is observed in a study conducted by Keane WF et al, where in most of the patients were receiving calcium channel blockers. ${ }^{11}$

In present study the WHO core prescription indicators were analysed. Generic drugs prescribed were $85 \%$ and $95 \%$ of medicines were prescribed from essential drug list. Percentage of injections was $8 \%$. The Injection prescribed here refers to insulin mixtard prescribed for the treatment of diabetes mellitus.

Different combination therapy of prescription pattern of anti hypertensive drugs in patients with diabetes as well as hypertension. Enalapril (ACE Inhibitor) was commonly used monotherapy drug, losarlan and amlodipine was used as two drug therapy. Enalapril, amlodipine and atenolol were used as Three drug therapy. Higher use of combination antihypertensive drug therapy in relation to monotherapy is similar to study done in Chandigarh. ${ }^{11,12}$

In other similar studies done, in patients suffering with diabetes and hypertension ACEI were more frequently utilized as monotherapy and for 2 drug therapy ARB's and CCB's were used and for their drug therapy ACEI+ CCB's+ betablockers were used. ${ }^{13,14}$ The other drugs apart from anti hypertensive are antiulcer agents $55 \%$, antimicrobials $15 \%$, injections $8 \%$, aspirin 20\%, metformin $26 \%$.

\section{CONCLUSION}

In the present study antihypertensive drugs commonly used are angiotensin receptor blockers, angiotensin converting enzyme inhibitors, calcium channel blockers and beta blockers. Other co-morbidities associated with hypertension are diabetes and also hypo and hyperthyroidism and respiratory infection. Majority of the drugs were prescribed as generic and most of them are from essential drug list. The injections used in present study were insulin prescribed for the treatment of diabetes. The study emphasizes that the need of rational prescribing of drugs by conducting continuing medical educational programs. And also, that increase prevalence of hypertension, cardiovascular diseases, diabetes, and other diseases must be addressed and effective control measures should be implemented.

\section{ACKNOWLEDGEMENTS}

Authors thankful to Professor and H.O.D and other staff and faculty of Department of Medicine, and also thankful to the faculty of Pharmacology Department for their valuable suggestions.

\section{Funding: No funding sources} Conflict of interest: None declared

Ethical approval: The study was approved by the Institutional Ethics Committee

\section{REFERENCES}

1. Anchala R, Kannuri NK, Pant H, Khan H, Franco OH, Di Angelantonio E, et al. Hypertension in India: a systematic review and meta-analysis of prevalence, awareness, and control of hypertension. J Hypertension. 2014 Jun;32(6):1170.

2. WHO. What is drug utilization research and why it is needed? In: introduction to drug utilization researchWorld Health Organization; 2003:8-12. Available at: http://apps.who.int/medicinedocs/pdf/s4876e/s4876e. pdf. Accessed 14 May 2016.

3. WHO. Drug classification systems. In: introduction to drug utilization research-World Health Organization; 2003:33-37. Available at: http://apps.who.int/medicinedocs/pdf/s4876e/s4876e. pdf. Accessed 14 May 2016.

4. WHO. Drug utilization metrics and their application. In: introduction to drug utilization research-World Health Organization; 2003:38-41. Available at: http://apps.who.int/medicinedocs/pdf/s4876e/s4876e. pdf. Accessed 16 May 2016.

5. Lakka HM, Laaksonen DE, Lakka TA, Niskanen LK, Kumpusalo E, Tuomilehto J, et al. The metabolic syndrome and total and cardiovascular disease mortality in middle-aged men. JAMA. 2002 Dec 4;288(21):2709-16.

6. Xavier D, Mathew N, Pradeep J, Pais P. Pattern of drug use in hypertension in a tertiary hospital: a cross sectional study in the in-patient wards. Indian $\mathbf{J}$ Pharmacol. 2001;33(6):456-7.

7. Isenalumhe AE, Oviawe O. Polypharmacy: its cost burden and barrier to medical care in a drug-oriented health care system. Int J Health Services. 1988 Apr;18(2):335-42.

8. Mohd AH, Mateti UV, Konuru V, Parmar MY, Kunduru BR. A study on prescribing patterns of antihypertensives in geriatric patients. Perspectives Clinical Research. 2012 Oct;3(4):139.

9. Beg MA, Dutta S, Varma A, Kant R, Bawa S, Anjoom $M$, et al. A study on drug prescribing pattern in hypertensive patients in a tertiary care teaching hospital at Dehradun, Uttarakhand. Int J Med Sci Public Health. 2014 Aug 1;3(8):922-7.

10. Kaur S, Gupta S, Kumar D, Lal M, Gilani Z. Prescribing pattern of antihypertensive drugs in a tertiary care hospital in Jammu: a descriptive study. JK-Practitioner. 2012 Oct;17(4):38-41.

11. Keane WF, Anderson S, Aurell M, de Zeeuw D, Narins RG, Povar G. Angiotensin converting enzyme inhibitors and progressive renal insufficiency: current experience and future directions. Ann Internal Med. 1989 Sep 15;111(6):503-16.

12. Malhotra S, Karan R, Pandhi P, Jain S. Pattern of use and pharmacoeconomic impact of antihypertensive drugs in a north Indian referral hospital. European J Clin Pharmacol. 2001 Sep 1;57(6-7):535-9.

13. Nakanishi N, Okamoto M, Yoshida H, Matsuo Y, Suzuki K, Tatara K. Serum uric acid and risk for development of hypertension and impaired fasting 
glucose or Type II diabetes in Japanese male office workers. European J Epidemiol. 2003 Jun $1 ; 18(6): 523-30$.

14. Uusitupa M, Siitonen O, Aro A, Pyörälä K. Prevalence of coronary heart disease, left ventricular failure and hypertension in middle-aged, newly diagnosed type 2 (non-insulin-dependent) diabetic subjects. Diabetologia. 1985 Jan 1;28(1):22-7.

Cite this article as: Radhika AR. Drug utilization study of antihypertensive drugs in a tertiary care hospital. Int J Basic Clin Pharmacol 2018;7:2309-13. 